\title{
Dosage and temporal dependent Arsenic-induced mortality in Ceriodaphnia dubia: An effective Biomarker for Arsenic Pollution
}

\author{
Soumendra Nath Talapatra ${ }^{1}$, Sayan Bhattacharya ${ }^{1,4, \star}$, Gunjan Guha ${ }^{2}$, \\ Subhayan Dutta ${ }^{1}$, Dhrubajyoti Chattopadhyay ${ }^{3}$, Aniruddha Mukhopadhyay ${ }^{1}$ \\ ${ }^{1}$ Department of Environmental Science, University of Calcutta. 51/2, Hazra Road, Kolkata 700 019, \\ West Bengal, India \\ ${ }^{2}$ Department of Pharmaceutical Sciences, College of Pharmacy, Oregon State University, \\ Corvallis, OR, USA \\ ${ }^{3}$ B.C. Guha Centre for Genetic Engineering and Biotechnology, University of Calcutta 35, Ballygunge \\ Circular Road, Kolkata - 700019, India \\ ${ }^{4}$ Department of Environmental Studies, Rabindra Bharati University, Kolkata, India \\ Phone: +919830950351 \\ *E-mail address: sayan_evs@yahoo.co.in
}

\begin{abstract}
Arsenic (As) is a metalloid that causes severe water pollution due to its extravagant toxicity. Ceriodaphnia dubia, a freshwater crustacean, was selected as a model system to evaluate the degree of time and dosage dependent acute toxicity caused by pentavalent As $[\mathrm{As}(\mathrm{V})]$. C. dubia were collected from a natural pond and treated with different concentrations of $\mathrm{As}(\mathrm{V})$ for 24 hours and 48 hours. For both 24 hours and 48 hours treatment periods, the mortality rates were increased significantly $(P<$ $0.05)$ with increase in $\mathrm{As}(\mathrm{V})$ concentrations. Simultaneously, it was also observed that $\mathrm{As}(\mathrm{V})$ induced mortality in C. dubia also depended on the time of exposure to the metalloid. We propose this model as a low-cost technique towards rapid screening of water quality in relation to As contamination.
\end{abstract}

Keywords: Arsenic; Water pollution; Ceriodaphnia dubia; Biomarker

\section{INTRODUCTION}

Arsenic (As) is a metalloid of severe environmental concern due to its extravagant toxicity and abundance (Bissen and Frimmel 2003). It is known to cause deleterious effects in both plants and animals through the metabolic pathways (Liu et al. 2005; McGeachy and Dixon 1989). Inorganic as well as organic forms of As are present in the environment, 
and the former seems to be more toxic and slightly more accumulated in some freshwater aquatic species than the latter (Spehar et al. 1980). Being a potent endocrine disruptor, it can alter hormone-mediated cell signaling even at extremely low concentrations in such organisms (Kaltreider et al. 2001). Water contamination by As has been extensively reported in India, China, Taiwan, Bangladesh, Vietnam, USA, Argentina, Chile and Mexico (WHO 2001).

The freshwater microcrustacean Ceriodaphnia dubia (common name: water flea, order: Cladocera) can be used in short-term standardized tests to estimate the acute or chronic toxicity of different metals, chemicals and effluents (Naddy et al. 1995; Peters et al. 1991). Naddy et.al. (1995) examined the sublethal interactive effects of arsenic (As), molybdenum (Mo), and selenium (Se) on Ceriodaphnia dubia using the three-brood static renewal toxicity test. Results showed that these metals can significantly reduce C. dubia fecundity. According to Cooper et.al. (2009), combination of copper and zinc can increase mortality rate of $C$. dubia significantly.

The use of this organism is justified because of its widespread geographic distribution and for taking an intermediate position in pelagial or planktonic food webs as it consumes algae and detritus and in turn is consumed by various predators. Ceriodaphnia is very sensitive to various toxic chemicals, is easily reared under laboratory conditions, and has a moderately short life cycle.

The current study was aimed at investigating the dosage and temporal dependence of As(V)-induced acute toxicity in Ceriodaphnia dubia. The bioassay was performed towards the development of an economic model for water quality testing in the context of As contamination.

\section{METHODS}

\section{1. Chemicals and Reagents}

Sodium arsenate dibasic heptahydrate $\left(\mathrm{Na}_{2} \mathrm{HAsO}_{4} \cdot 7 \mathrm{H}_{2} \mathrm{O}\right)$ procured from Sigma-Aldrich Chemical Co. (Milwaukee, WI, USA). The remaining chemicals used were of standard analytical grade.

\section{2. Culture and maintenance of $C$. dubia}

C. dubia were collected from a natural pond located in Kolkata $\left(22^{\circ} 34^{\prime} \mathrm{N}, 88^{\circ} 22^{\prime} \mathrm{E}\right)$, India. They were cultured at $25^{\circ} \mathrm{C}$ with a $2: 1$ photoperiod in $100 \mathrm{ml}$ of chlorine-free water in a glass jar and were fed with yeast (Hansen et al. 2002). One day prior to performing the acute toxicity test, 30 mature females were transferred to $150 \mathrm{ml}$ fresh water. The parthenogenetic females reproduced rapidly and a large number of neonates were formed. After $24 \mathrm{~h}$, the neonates were collected and transferred to a new jar. These neonates (less than $24 \mathrm{~h}$ old) were used for the acute $\mathrm{As}(\mathrm{V})$-induced toxicity test.

\section{3. Acute $\operatorname{As}(\mathbf{V})$ toxicity bioassay}

$\mathrm{Na}_{2} \mathrm{HAsO}_{4} \cdot 7 \mathrm{H}_{2} \mathrm{O}$ was dissolved in chlorine-free water in four concentrations $(10,30,50$ and $70 \mu \mathrm{g} / \mathrm{L})$ to prepare the $\mathrm{As}(\mathrm{V})$-containing test solution. 10 neonates were transferred to $150 \mathrm{ml}$ of each concentration of the test solution and maintained without disturbance for $24 \mathrm{~h}$. Another set of 10 neonates were similarly transferred to $150 \mathrm{ml}$ of each of the four concentrations of the test solution and kept undisturbed for $48 \mathrm{~h}$. These were the two test 
groups ( $24 \mathrm{~h}$ and $48 \mathrm{~h}$ test groups, respectively). Additionally, two sets of neonates (each containing 10 individuals) were also maintained in chlorine-free water for 24 and $48 \mathrm{~h}$ as control groups for the respective $24 \mathrm{~h}$ and $48 \mathrm{~h}$ test groups. No feeding and aeration were provided to the neonates of these four sets during the test (Eaton et al. 1995).

The $24 \mathrm{~h}$ test and control groups were examined under 10x magnification after $24 \mathrm{~h}$ to determine percentage mortality in all concentrations of $\operatorname{As}(V)$ in the test group. Similarly, percentage mortality with varying $\mathrm{As}(\mathrm{V})$ concentrations were also evaluated in the $48 \mathrm{~h}$ test group with respect to the $48 \mathrm{~h}$ control. An organism was pronounced dead when no heartbeat was detected for $15 \mathrm{sec}$. The $\mathrm{LC}_{50}$ values for all test samples for $24 \mathrm{~h}$ and $48 \mathrm{~h}$ duration of treatment were also calculated by probit analysis (Fisher and Yates, 1974). Significant differences between the groups were determined by one-way ANOVA at $\mathrm{P}<0.05$. MATLAB ver. 7.0 (Natick, MA, USA) and Microsoft Excel 2007 (Roselle, IL, USA) were used for the statistical and graphical evaluations.

\section{RESULTS}

Fig. 1 demonstrates that $\mathrm{As}(\mathrm{V})$ caused extensive mortality in $C$. dubia. For both 24 hours and 48 hours treatment periods, the mortality rates were increased significantly $(P<$ $0.05)$ with increase in $\mathrm{As}(\mathrm{V})$ concentrations. Additionally, $\mathrm{As}(\mathrm{V})$-induced mortality in $C$. dubia was increased with the time of exposure to the metalloid.
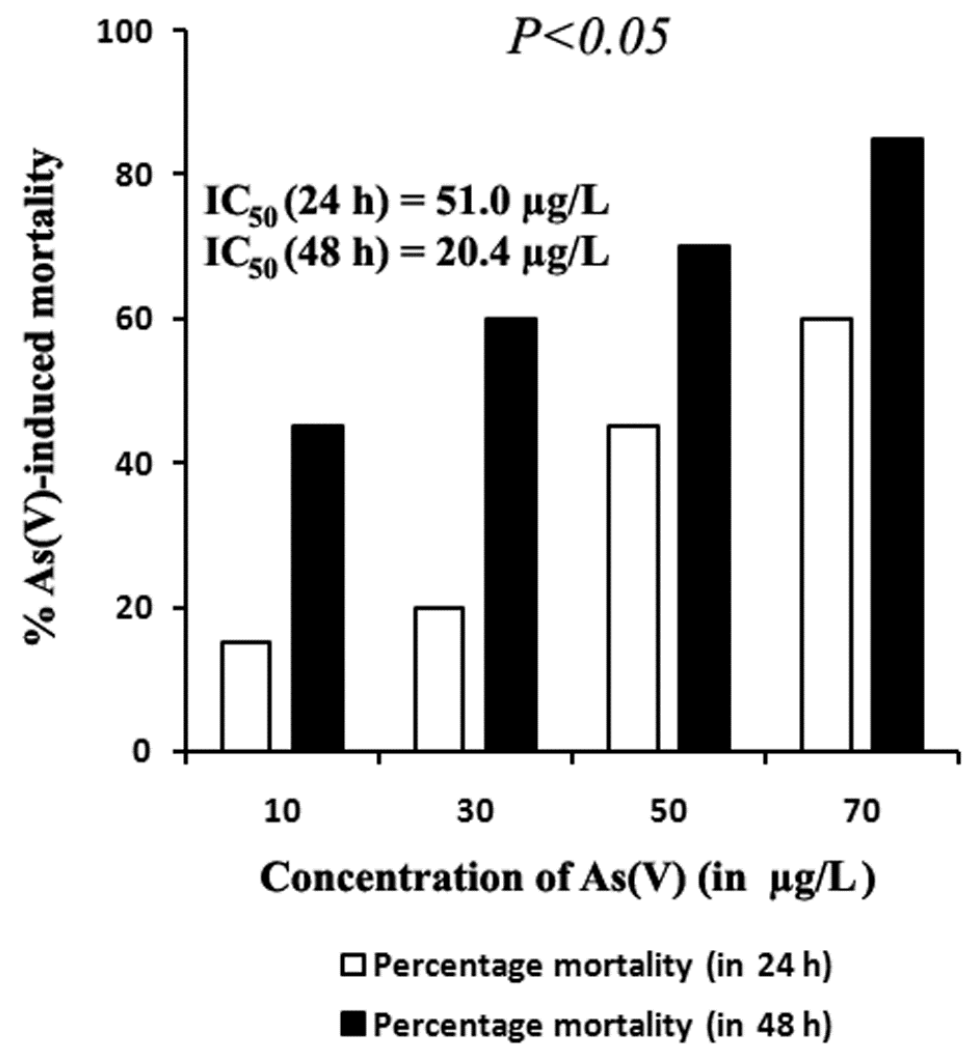

Figure 1. Percentage mortality in C. dubia due to As(V) exposure (to diverse dosages) for 24 and 48 h. Data were tested for significant difference between groups at $P<0.05 . \mathrm{IC}_{50}$ values for the treatment groups were evaluated by probit analysis. 
Significantly $(P<0.05)$ higher percentages of mortality were observed for all concentrations in the 48 hours exposure group in comparison to the 24 hours exposure group. $\mathrm{As}(\mathrm{V}) \mathrm{LC}_{50}$ values for the $24 \mathrm{~h}$ and $48 \mathrm{~h}$ test groups were respectively 51 and $20.4 \mu \mathrm{g} / \mathrm{L}$. Since a smaller $\mathrm{LC}_{50}$ value denotes higher lethality, it was confirmed that a longer exposure to As $(\mathrm{V})$ caused more mortality in C. dubia. Time of exposure and the concentration of the toxicant, both affect the experimental organisms significantly.

The results of the current study clearly revealed that $C$. dubia is highly sensitive towards As(V)-induced toxicity. Hence, C. daphnia can be used as a biomarker for As pollution of aquatic ecosystems. The permissible limit for As in water is $10 \mathrm{ppb}(10 \mu \mathrm{g} / \mathrm{L})$, as recommended by the World Health Organization (WHO 2001). C. daphnia was found to show up to $15 \%$ and $45 \%$ mortality at this threshold concentration for 24 and $48 \mathrm{~h}$ exposure periods respectively. Thus, the species was observed to be considerably sensitive to As in the form of arsenate $\mathrm{As}(\mathrm{V})$.

\section{CONCLUSION}

The current study reports for the first time the toxicity of $\mathrm{As}(\mathrm{V})$ in $C$. dubia with respect to varying dosages and exposure periods. In this context, we propose that the crustacean might be used as a model biomonitoring system for detecting As contamination in water. Such biomonitoring might not only be limited in testing samples from aquatic ecosystems, but may also be extended towards screening groundwater and/or drinking water samples in As-prone areas. However, further research is in prospect to determine of As susceptibility of C. dubia when in combination with other aquatic toxicants.

\section{Abbreviations}

As - arsenic; $\mathrm{As}(\mathrm{V})$ - pentavalent arsenic; $\mathrm{LC}_{50}$ - lethal concentration 50.

\section{Acknowledgement}

The authors convey their gratitude to the Department of Environmental Science, University of Calcutta, for providing the necessary infrastructure and financial support for doing this study.

\section{References}

[1] Bissen M., Frimmel F. H., Acta Hydrochim Hydrobiol 31 (2003) 9-18.

[2] Cooper N. L., Bidwell J. R., Kumar A., Ecotoxicol Environ Safety 72 (2009) 1523-1528.

[3] Eaton A. D., Clesceri L. S., Greenberg A. E., Standard Methods for the Examination of Water and Wastewater, nineteenth ed. American Public Health Association, USA. 1995.

[4] Fisher R. A., Yates F., Statistical table for Biological, Agricultural and Medical Research, Longman, London. 1974.

[5] Hansen L. J., Whitehead J. A., Anderson S. L., Ecotoxicol 11(4) (2002) 279-287.

[6] Kaltreider R. C., David M. A., Lariviere J. P., Hamilton J. W., Environ Health Perspect 109 (2001) 245-251.

[7] Liu X., Zhang S., Shan X., Zhu Y. G., Chemosphere 61(2) (2005) 293-301. 
[8] McGeachy S. M., Dixon D. G., Ecotoxicol Environ Saf 17(1) (1989) 86-93.

[9] Naddy R. B., La Point T. W., Klaine S. J., Environ Toxicol Chem 14 (1995) 329-336.

[10] Peters G. T., Burton D. T., Pauilson R. L., Turley S. D., Environ Toxicol Chem 10 (1991) 1073-1081.

[11] Spehar R. L., Fiandt J. T., Anderson R. L., Defoe D. L., Arch Environ Contam Toxicol 9 (1980) 53-63.

[12] WHO. United Nations synthesis report on arsenic drinking water. World Health Organization, Geneva. 2001. 